\title{
Two new weevil genera of the family Brentidae (Coleoptera) in Baltic amber
}

\author{
Andrei A. Legalov
}

Legalov, A. A. 2018: Two new weevil genera of the family Brentidae (Coleoptera) in Baltic amber. — Entomol. Fennica 29: 161-168.

Two new genera and two new species, Baltocyba gen. n. (type species: $B$. electrinus sp. n.) and Baltonanophyes gen. n. (type species: $B$. crassirostre sp. n.), and two new species, Baltocyba electrinus sp. n. and Baltonanophyes crassirostre sp. n., from the Baltic amber are described and illustrated. The genus Archinvolvulus Voss, 1972, placem. n. is transferred from the tribe Rhadinocybini to the tribe Notapionini.

A. A. Legalov, Institute of Systematics and Ecology of Animals, Siberian Branch, Russian Academy of Sciences, Frunze Street, 11, Novosibirsk 630091, Russia. E-mail:fossilweevils@gmail.com

Received 11 January 2018, accepted 9 February 2018

\section{Introduction}

Weevils of the family Brentidae include about 4,400 species in the recent fauna (Oberprieler 2014a). The earliest known brentid subfamily Eurhynchinae was described from the AptianAlbian of Santana in Brazil (Zherikhin \& Grachev 2004). Recent forms of this subfamily live in Australia and New Guinea (Oberprieler 2014b). The most ancient Apioninae is known from the Turonian of Kzyl-Dzhar in Kazakhstan (Legalov 2014). Representatives of the subfamily Apioninae are also known from the Paleocene of the Primorski Region (Legalov 2015b), the Eocene French and Baltic ambers (Kirejtshuk et al. 2015, Legalov 2015b, Legalov \& Bukejs 2015), Middle Eocene of Green River (Scudder 1893, Legalov 2018c), terminal Eocene of Florissant (Scudder 1893, Legalov 2013, 2015a), Miocene Dominican amber (Poinar \& Legalov 2015) and several Oligocene and Miocene European and Chinese locations (Legalov 2015b). Modern Apioninae are known everywhere. The earliest member of Nanophyinae was described from the
early-Middle Eocene of the Green River (Legalov 2015a) and was recorded also from Late Eocene in Baltic amber (Klebs 1910). Three species of the subfamily has been described only from the Eocene of USA and France (Théobald 1937, Legalov 2015b) and Oligocene of Germany (Heyden \& Heyden 1866). Currently weevils of Nanophyinae occur in Holarctic, Oriental, Ethiopian and Australian Regions (AlonsoZarazaga 2014).

The oldest Brentinae are known from the Middle Eocene of Germany (Messel and Maar) (Lutz 1990, Tröster 1993, Wappler 2003) and its representatives have been described from the early-Middle Miocene Dominican amber (Poinar 2009). Now its representatives occur widespread in tropical regions. The fossil Cyladinae weevils were recently described from the Middle Miocene of Öhningen (Germany) (Legalov 2018a). The representatives of that subfamily currently live in the Oriental and Ethiopian Regions, and Cylas formicarius (Fabricius, 1798) was introduced to the New World (Alonso-Zarazaga \& Lyal 1999). 
Two new genera with a new species in each, representing subfamilies Apioninae and Nanophyinae in the weevil family Brentidae, found in the Baltic amber, are here described for the first time. A new systematic placement of Archinvolvulus Voss, 1972 is established.

\section{Materials and methods}

The weevil fossils, which the descriptions of the new genera and species are based on, originate from the largest known deposits of amber, called Baltic amber or succinate, are located along the Baltic Sea coast at the Amber quarry of Yantarny near Kaliningrad in the Kaliningrad Oblast, Russia. The amber from this deposit was probably produced by the Sciadopitys sp., a conifer tree of the family Sciadopityaceae, with only one currently living species in the temperate regions of central and western Japan (Sadowski et al. 2016). The Baltic amber from this Prussian Formation dates from middle (Ritzkowski 1997) to upper Eocene (Aleksandrova \& Zaporozhets 2008).

The holotypes of the new species are stored in the Institute of Systematics and Ecology of Animals, the Siberian Branch of the Russian Academy of Sciences (Novosibirsk, Russia). Comparative material is deposited in the Institute of Systematics and Ecology of Animals, Museum für Tierkunde, Senckenberg Naturhistorischen Sammlungen Dresden (Germany), the Zoological Institute of the Russian Academy of Sciences and the Zoological Museum, University of Copenhagen (Copenhagen, Denmark).

Descriptions, body measuring, and photographs, were performed using the Zeiss Stemi 2000-C dissecting stereomicroscope.

The systematics of studied taxa are from Bouchard et al. (2011) and Legalov (2018b). The terminology of weevil body is according to Lawrence et al. (2010).

\section{Description of Baltocyba gen. $n$. and $B$. electrinus sp. $\mathbf{n}$.}

Brentidae Billberg, 1820

Apioninae Schoenherr, 1823

Rhadinocybini Alonso-Zarazaga, 1992

\section{Baltocyba gen. n.}

Type species: Baltocyba electrinus sp. n., described below.

Diagnosis. This new genus is similar to the genus Rhadinocyba Faust, 1889 from New Caledonia but differs from it by the short temples, coarsely punctate pronotum and strong convexity behind the middle of the body (lateral view).

Etymology. The name is formed from the Latin word for "Baltic" - "balticum" and part of the generic name "cyba".

Remarks. The new genus and species belong to brentids based on the long ventrites 1 and 2 and short ventrites 3-5 oriented in different planes, antennae being straight, and tibiae without uncus and without two groups of setae at apex. The femora not joining with coxae, trochanters being elongate and rostrum with deep scrobes, suggest placement in the subfamily Apioninae. The elytral stria 10 merges with stria 9 near metacoxa, mesocoxal cavities being contiguous, the greatest width of pronotum being located in the apical third, scape being slightly larger than antennomeres 2-5 combined, and elytral striae being without sharp edges show that the new genus belongs to the tribe Rhadinocybini.

\section{Description of Baltocyba electrinus sp. $\mathbf{n}$.}

(Fig. 1)

Type material. Holotype: no. BA2017/9.

Description. Male. Body length (without rostrum) $4.3 \mathrm{~mm}$, rostrum length $1.0 \mathrm{~mm}$.

Body. Black, naked, appearing silvery shiny due to the presence of cavities between specimen and internal surface of its impression.

Head. Rostrum almost straight, 1.2 times as long as pronotum, 3.3 times as long as wide at apex, 3.1 times as long as wide in middle, 2.9 times as long as wide at base, finely punctate; scrobes deep and sulciform, directed under eyes; forehead 0.7 times as narrow as rostrum base, flattened, punctate; eyes large, rounded, convex; vertex weakly flattened, finely punctate; temples 0.6 times as long as diameter of eye, strigose; antennae straight, inserted near middle of rostrum laterally; antennae reaching pronotum; antennomere 15.6 times as long as wide, not reaching to 

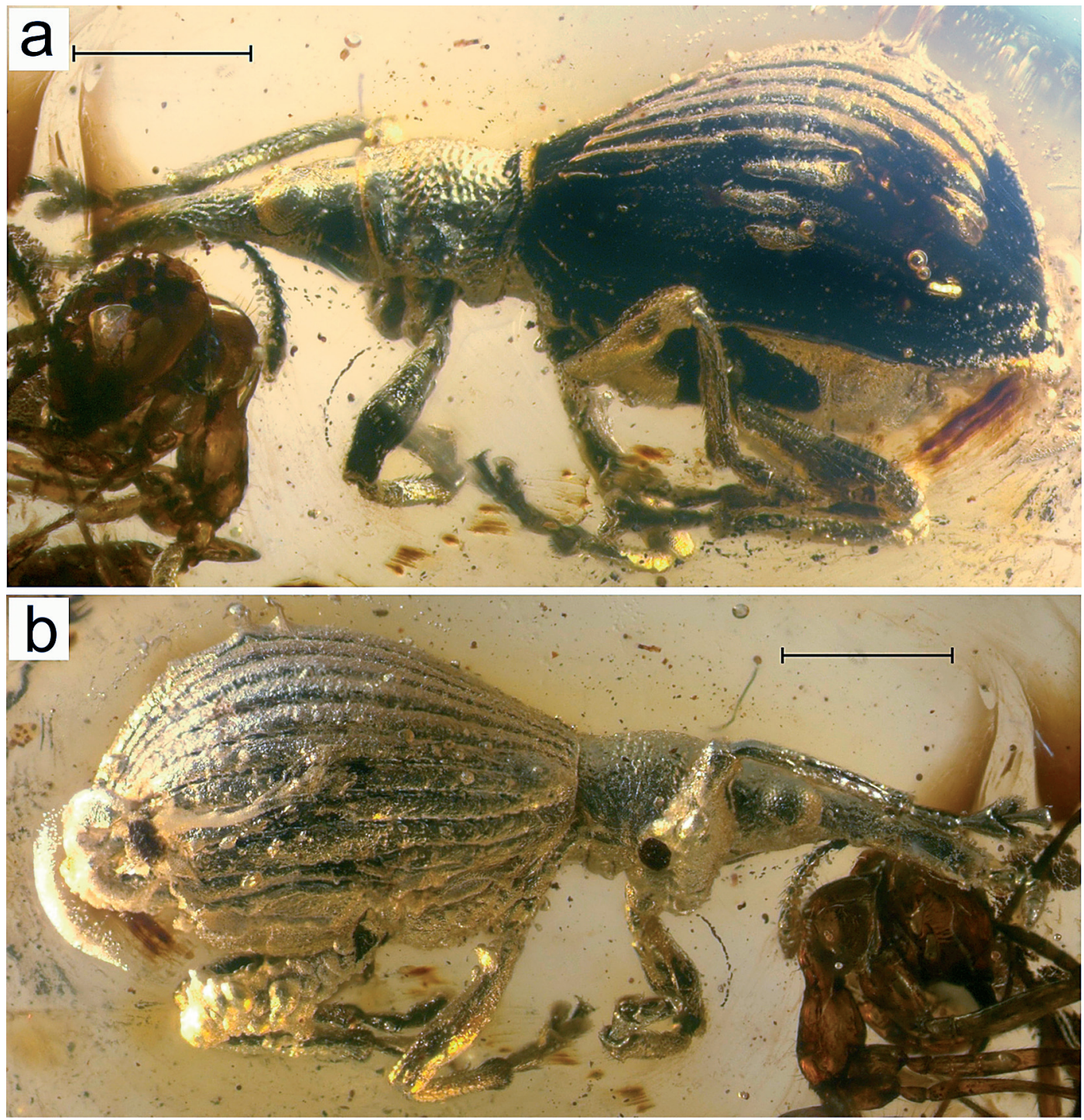

Fig. 1. Habitus of Baltocyba electrinus sp. n. male (holotype). - a. Lateral view, left. - b. Lateral view, right. Scale bars $1 \mathrm{~mm}$.

eyes, slightly longer than antennomeres $2-5$ combined; antennomeres 2-8 conical; antennomere 2 2.0 times as long as wide, 0.4 times as long and similar in width with antennomere 1; antennomere 32.3 times as long as wide, 0.9 times as long and 0.8 times as narrow as antennomere 2 ; antennomeres 3-5 subequal in width; antennomere 4 1.4 times as long as wide, 0.6 times as long as antennomere 3 ; antennomere 5 similar with antennomere 4; antennomere 61.7 times as long as wide, similar in length and 0.9 times as narrow as antennomere 5; antennomere 71.5 times as long as wide, 1.2 times as long and 1.3 times as wide as antennomere 6; antennomere 81.1 times as long as wide, 0.9 times as long as and 1.3 times as wide as antennomere 7; club loose, 3.3 times longer than wide, 0.8 times as long as antennomeres $2-8$ combined; antennomere 90.8 times as long as wide, 1.1 times as long and 1.6 times as wide as antennomere 8; antennomere 100.7 times as long as wide, 0.8 times as long and similar in width with antennomere 9; antennomere 111.7 times as long as wide, 2.4 times as long and 0.9 times as narrow as antennomere 10, weakly acuminate. 
Diameter of eye $0.4 \mathrm{~mm}$; length of antennae 1.3 $\mathrm{mm}$; length of club $0.35 \mathrm{~mm}$.

Pronotum. With subapical constriction, 1.1 times as long as wide at apex, 0.9 times as long as wide in middle, 1.1 times as long as wide at base; widest in middle; disk convex, coarsely punctate; pronotum widest in apical third; scutellum triangular, small. Length of pronotum $0.9 \mathrm{~mm}$; width of pronotum at apex and at base $0.89 \mathrm{~mm}$; width of pronotum in middle $0.97 \mathrm{~mm}$.

Elytra. Pear-shaped, strongly convex behind middle (lateral view), 2.1 times as long as wide at base, 1.7 times as long as wide in middle, 2.5 times longer than wide in apical quarter, 2.5 times as long as pronotum; humeri weakly rounded; punctured striae regular and distinct, lacking sharp edges; stria 10 merging with stria 9 near metacoxa; intervals weakly convex, wide, 5.0 6.0 times as wide as striae. Length of elytra 3.19 $\mathrm{mm}$; width of elytra at base $1.32 \mathrm{~mm}$; width of elytra in middle $2.08 \mathrm{~mm}$; width of elytra in apical quarter $1.12 \mathrm{~mm}$.

Thorax. Prosternum densely punctate; precoxal part of prosternum short, 0.3 times as long as procoxa length; postcoxal part of prosternum long, 0.7 times as long as procoxa; procoxal cavities round, contiguous; metaventrite long, 2.3 times as long as metacoxa, convex, densely punctate; metepisternum 1.9 times as long as wide, punctate. Length of prosternum $0.66 \mathrm{~mm}$; length of metaventrite $0.78 \mathrm{~mm}$.

Legs. Procoxae conical; metacoxae transverse; trochanters conical, elongate; femora weakly clavate, not joining with coxae, without teeth; tibiae almost straight, weakly flattened, widened at apices, with apical dark setose fringe, without uncus and without two groups of setae at apex; tarsi long, with thick light erect setae dorsally; tarsomeres 1 and 2 trapezoidal; tarsomere 3 bilobed; tarsomere 4 small; tarsomere 5 elongate; claws large, free, strongly divergent; protarsi: tarsomere 12.8 times as long as wide; tarsomere 2 1.2 times as long as wide, 0.7 times as long and 1.7 times as wide as tarsomere 1 ; tarsomere 30.7 times as long as wide, 0.7 times as long and 1.1 times as wide as tarsomere 2; tarsomere 53.7 times as long as wide, 1.6 times as long and 0.3 times as wide as tarsomere 3; mesotarsi: tarsomere 11.5 times as long as wide; tarsomere 21.1 times as long as wide, 0.8 times as long and 1.1 times as wide as tarsomere 1; tarsomere 30.7 times as long as wide, 0.8 times as long and 1.2 times as wide as tarsomere 2; tarsomere 52.6 times as long as wide, 1.1 times as long and 0.3 times as wide as tarsomere 3; metatarsi: tarsomere 11.9 times as long as wide; tarsomere 2 similar in length and width, and 0.5 times as long as and 0.9 times as wide as tarsomere 1 ; tarsomere 30.8 times as long as wide, and 1.4 times as long and 1.7 times as wide as tarsomere 2 ; tarsomere 52.3 times as long as wide, 0.8 times as long and 0.3 times as wide as tarsomere 3 . Length of profemur $1.0 \mathrm{~mm}$; width of profemur $0.29 \mathrm{~mm}$; length of mesofemur $1.05 \mathrm{~mm}$; width of mesofemur 0.26 $\mathrm{mm}$; length of metafemur $1.23 \mathrm{~mm}$; width of metafemur $0.33 \mathrm{~mm}$; length of protibia $1.16 \mathrm{~mm}$; width of protibia $0.13 \mathrm{~mm}$; length of mesotibia $0.89 \mathrm{~mm}$; width of mesotibia $0.16 \mathrm{~mm}$; length of metatibia $1.09 \mathrm{~mm}$; width of metatibia $0.15 \mathrm{~mm}$.

Abdomen. Convex; ventrites 1 and 2 and ventrites 3-5 oriented in different planes; ventrite 11.9 times as long as metacoxa; ventrite 20.9 times as long as ventrite 1 ; ventrites 3 and 4 subequal in length; ventrite 30.3 times as long as ventrite 2; ventrite 54.0 times as long as ventrite 4. Length of abdomen $1.6 \mathrm{~mm}$.

Type locality and type strata. Amber deposits located along the Baltic Sea coast and Yantarny Amber quarry near Kaliningrad, Kaliningrad region, Russia, middle-upper Eocene, Prussian Formation.

Etymology. The name is formed from the Latin word for "amber" - "electri".

\section{Description of Baltonanophyes gen. $n$. and $B$. crassirostre sp. $n$.}

Brentidae Billberg, 1820

Nanophyinae Gistel, 1856

Nanophyini Gistel, 1856

\section{Baltonanophyes gen. $\mathrm{n}$.}

Type species: Baltonanophyes crassirostre sp. n., described below.

Diagnosis. This new genus belongs to the group of the archaic genera: Diplophyes Marshall, 1933, Indophyes Friedman, 2012, Lyalia Alonso-Zarazaga et Perrin, 2011, Meregallia 
Alonso-Zarazaga, 1990, Oxycorax AlonsoZarazaga, 1990, Shiva Pajni et Bhateja, 1982 and Zherikhinia Alonso-Zarazaga, 1999, with complete elytral stria 10. From the genera Diplophyes, Indophyes, Meregallia, Oxycorax, Shiva and Zherikhinia, it is distinguished by the base of elytral interval 8 having complete crenulate carina. The new genus differs from Oriental Lyalia in the almost straight and thick rostrum, convex eyes, and elongate body. From Middle Eocene Palaeonanophyes Legalov, 2015 from Green River, the new genus differs in the almost straight and thick rostrum, strongly thickened femora and large body size.

Etymology. The name is formed from the Latin word for "Baltic" - "balticum" and the generic name Nanophyes.

Remarks. The new genus Baltonanophyes belongs to brentids based on the similar characters (excluding the antennae) as in the previous genus Baltocyba gen. n. Procoxal cavities being contiguous, femora not joining with coxae, trochanters being elongate, antennae geniculate, scrobes shallow, scutellum concealed and base of elytra having crenulate carina, suggest placement Baltonanophyes in the subfamily Nanophyinae. Tarsomere 5 having two fused claws and antennal club having loose segments place the new genus in the tribe Nanophyini

\section{Description of Baltonanophyes crassirostre} sp. n. (Fig. 2)

\section{Type material. Holotype: no. BA2017/10.}

Description. Male. Body length (without rostrum) $2.5 \mathrm{~mm}$; rostrum length $0.9 \mathrm{~mm}$.

Body. Black, covered with short decumbent hairs, appearing silvery shiny due to presence of cavities between specimen and internal surface of its impression.

Head. Rostrum almost straight and thick, 1.3 times as long as pronotum, at apex 4.7 times as long as wide, in middle and at base 5.2 times as long as wide, finely punctate; scrobes shallow, directed to eyes; forehead 0.8 times as wide as of rostrum base, flattened, punctate; eyes large, convex, 0.9 times as long as wide; vertex weakly flattened, finely punctate; temples 0.4 times as long as diameter of eye; antennae geniculate, inserted at sides of apical third of rostrum; antennae reach- ing middle of pronotum; antennomere 115.0 times as long as wide, not reaching to eyes; antennomeres 2-7 conical; antennomere 22.5 times as long as wide, 0.2 times as long and similar in width with antennomere 1; antennomere 33.4 times as long as wide, 1.2 times as long and 0.9 times as narrow as antennomere 2 ; antennomere 4 1.4 times as long as wide, 0.4 times as long and similar in width with antennomere 3 ; antennomere 5 similar with antennomere 4 ; antennomere 61.3 times as long as wide, 0.9 times as long and subequal in width with antennomere 5; antennomere 7 equal in length and width, and 0.9 times as long and 1.1 times as wide as antennomere 6 ; club loose, 2.7 times as long as wide, 0.7 times as long as antennomeres 2-7 combined; antennomere 8 1.1 times as long as wide, 2.3 times as long as and 2.0 times as wide as antennomere 7 ; antennomere 90.9 times as long as wide, 0.9 times as long as and 1.1 times as wide as antennomere 8; antennomere 10 twice as long as wide, 2.5 times as long and 1.1 times as wide as antennomere 9, weakly acuminate. Diameter of eye $0.25 \mathrm{~mm}$; length of club $0.39 \mathrm{~mm}$.

Pronotum. Bell-shaped, similar in length and width at apex, 0.9 times as long as wide in middle, 0.7 times as long as wide at base; widest at base; disk convex, finely and sparsely punctate; sides almost straight; scutellum concealed. Length of pronotum $1.57 \mathrm{~mm}$.

Elytra. Elongate and convex, about 1.8 times as long as wide at base, 1.5 times as long as wide in middle, 2.2 times as long as wide in apical quarter, 2.4 times as long as pronotum; base of elytra with crenulate carina; humeri weakly rounded; punctured striae regular and distinct; stria 10 complete; intervals weakly convex, wide, 5.0-6.0 times as wide as striae, with middle row of fine points; base of interval 8 with complete crenulate carina. Length of elytra $1.75 \mathrm{~mm}$.

Thorax. Prosternum finely punctate; pre- and postcoxal parts of prosternum very short; procoxal cavities round, contiguous; metaventrite short, subequal in length with metacoxa, convex, finely punctate; metepisternum 5.7 times as long as wide, densely punctate. Length of prosternum $0.43 \mathrm{~mm}$; length of metaventrite $0.25 \mathrm{~mm}$.

Legs. Legs long; procoxae conical; metacoxae transverse; trochanters conical, elongate; femora clavate, not joining with coxae, with three 


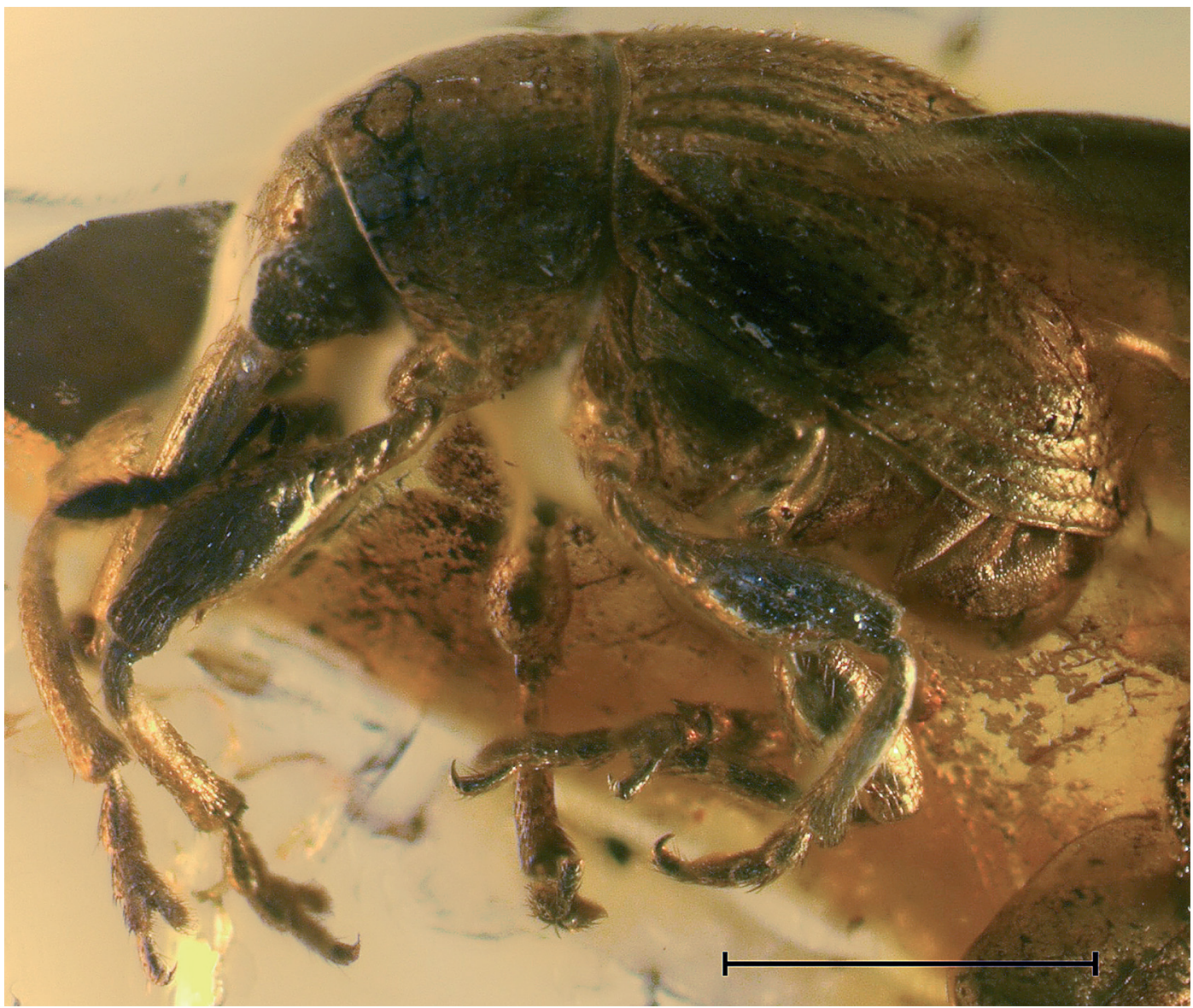

Fig. 2. Habitus of Baltonanophyes crassirostre sp. n. male (holotype). Lateral view, left. Scale bar $1 \mathrm{~mm}$.

teeth; tibiae almost straight, weakly flattened, widened at apices, with apical dark setose fringe, without uncus and without two groups of setae at apex; tarsi long, with thick light erect setae on above surface; tarsomeres 1 and 2 trapezoidal; tarsomere 3 bilobed; tarsomere 4 small; tarsomere 5 elongate; claws large, fused at base; protarsi: tarsomere 11.5 times as long as wide; tarsomere 2 similar in length and width 0.8 times as long and 1.2 times as wide as tarsomere 1 ; tarsomere 30.6 times as long as wide, 0.8 times as long and 1.3 times as wide as tarsomere 2; tarsomere 4 similar in length and width; tarsomere 53.3 times as long as wide, 1.7 times as long and 0.3 times as wide as tarsomere 3. Length of profemur $0.99 \mathrm{~mm}$; width of profemur $0.3 \mathrm{~mm}$; length of mesofemur 0.84 $\mathrm{mm}$; width of mesofemur $0.26 \mathrm{~mm}$; length of metafemur $0.73 \mathrm{~mm}$; width of metafemur 0.22 $\mathrm{mm}$; length of protibia $0.71 \mathrm{~mm}$; width of protibia
$0.12 \mathrm{~mm}$; length of mesotibia $0.6 \mathrm{~mm}$; width of mesotibia $0.11 \mathrm{~mm}$; length of metatibia $0.6 \mathrm{~mm}$; width of metatibia $0.11 \mathrm{~mm}$.

Abdomen. Convex; ventrites 1 and 2, and ventrites 3-5 oriented in different planes; ventrite 10.7 times as long as metacoxa; ventrite 2 subequal with ventrite 1 ; ventrites 3 and 4 subequal in length; ventrite 30.6 times as long as ventrite 2 ; ventrite 52.0 times as long as ventrite 4; pygidium convex. Length of abdomen 0.67 $\mathrm{mm}$.

Type locality and type strata. Amber deposit located along the Baltic Sea coast and Yantarny Amber quarry near Kaliningrad, Kaliningrad region, Russia, Middle-upper Eocene, Prussian Formation.

Etymology. The name is formed from the Latin words for "thick" - "crassis" and "rostrum" "rostra". 


\section{Discussion}

Weevil species representing two subfamilies, Nanophyinae and Apioninae of the family Brentidae, were found in Baltic amber. From this amber deposit also other species of the genera have been described: Pseudaspidapion Wanat, 1990, with one species of the tribe Aspidapiini; Melanapion Wagner, 1930, with tree species and Succinapion Legalov et Bukejs, 2015, with one species of Kalcapiini; Electrapion Wagner, 1924, with one species; Conapium Motschulsky, 1860, with one species of Piezotrachelini; and Stenapion Wagner, 1912, with one species of Apionini (Wagner 1924, Voss 1953, 1972, Zherikhin 1971, Legalov 2012, 2015b, Legalov \& Bukejs 2015).

Apion anderseni Voss, 1972 and Archinvolvulus liquidus Voss, 1972 have also been found in the amber deposit. The systematic position of $A$. anderseni needs to be clarified, because I cannot determine the generic position of this species by the original description. Archinvolvulus liquidus was described in the family Attelabidae (Voss 1972) but it was subsequently correctly transferred to the subfamily Apioninae in the family Brentidae. It was placed in the tribe Rhadinocybini (Kuschel 1992), but while describing Baltocyba electrinus sp. n., I re-examined the characters of A. liquidus, which I studied earlier (Legalov 2012). The genus Archinvolvulus Voss, 1972, placem. n. is characterized by the scratch-like elytral striae, the pronotum being widest near the middle and antennomere 1 almost as long as antennomeres 2 and 3 together. For these reasons, it is transferred here to the tribe Notapionini. Thus the Brentidae fauna of Baltic amber is currently represented by 11 species from nine genera (including two genera and species described here) of seven tribes.

Presently living beetles of the fossil groups in Baltic amber are encountered in Europe, North America, Oriental Region, South and East Africa, Eastern Australia and Andes meridional as shown in Alekseev's study (Alekseev 2017). The faunistic relations of Baltic amber weevils are analogical. The presently living representatives of the tribe Notapionini are distributed in Oriental Region, Eastern Australia, New Guinea, New Caledonia and other Melanesian islands (Wanat 2001). Recent genera of the tribe Rhadinocybini live now in New Caledonia. Six archaic Nanophyini genera, recorded from Oriental Region and Zherikhinia, are known from islands of East Asia (Alonso-Zarazaga \& Lyal 1999, AlonsoZarazaga \& Perrin 2011, Friedman 2012). The new data of the present study confirm the relations between fossil weevils in Baltic amber and modern species in Oriental and Australian Regions.

Acknowledgements. The author thanks O. Jaeger (Germany: Dresden), K.-D. Klass (Germany: Dresden), B. A. Korotyaev (Russia: St.-Petersburg) and L. B. Vilhelmsen (Copenhagen) for the opportunity to study comparative material, Dr. G. O. Poinar, Jr (USA: Corvallis) for improving the manuscript and two anonymous reviewers for the important comments on this manuscript. The study was partially supported by the Federal Fundamental Scientific Research Program for 2013-2020, project no. VI.51.1.5 and the Russian Foundation for Basic Research, project no. 18-04-00243-a.

\section{References}

Alekseev, V. I. 2017: Coleoptera from the middle-upper Eocene European ambers: generic composition, zoogeography and climatic implications. - Zootaxa 4290(3): 401-443.

Aleksandrova, G. N. \& Zaporozhets, N. I. 2008: Palynological characteristic of the Upper Cretaceous and $\mathrm{Pa}-$ leogene sediments of the West of the Sambian peninsula (the Kaliningrad Region). Part 2. - Stratigraphy and Geological Correlation 16(5): 75-86.

Alonso-Zarazaga, M. A. 2014: 3.6.4 Nanophyinae Gistel, 1848. - Handbook of Zoology. Arthropoda: Insecta. Tb. 40: Coleoptera (Beetles). Vol. 3: Morphology and Systematics (Phytophaga): 416-422.

Alonso-Zarazaga, M. A. \& Lyal, C. H. C. 1999: A world catalogue of families and genera Curculionoidea (Insecta: Coleoptera) (excepting Scolytidae and Platypodidae). - Barcelona, Entomopraxis. 316 p.

Alonso-Zarazaga, M. A. \& Perrin, H. 2011: Two new genera of Nanophyidae with six desmomeres (Coleoptera, Curculionoidea). - ZooKeys 125: 35-50.

Bouchard, P., Bousquet, Y., Davies, A. E., Alonso-Zarazaga, M. A., Lawrence, J. F., Lyal, C. H. C., Newton, A. F., Reid, C. A. M., Schmitt, M., Ślipiński, S. A. \& Smith, A. B. T. 2011: Family group names in Coleoptera (Insecta). - Zookeys 88: 1-972.

Friedman, A.-L.-L. 2012: Indophyes yaromi, a new genus and species of Nanophyidae (Curculionoidea) from southern India. - Zootaxa 3219: 54-61.

Heyden, C. \& Heyden, L. 1866: Käfer und Polypen aus der Braunkohle des Siebengebirges. - Palaeontographica 15: 131-156, XXII-XXIV.

Kirejtshuk, A. G., Legalov, A. A. \& Nel, A. 2015: A new 
genus of the subfamily Apioninae (Coleoptera: Brentidae) from the Lower Eocene Oise amber. - Paleontological Journal 49(13): 1436-1441.

Klebs, R. 1910: Über Bernsteinschlüsse im allgemein und die Coleopteren meiner Bernsteinsammlung. Schriften der Physikalisch-Ökonomischen Gesellschaft zu Königsberg im Prussia 51(3): 217-242.

Kuschel, G. 1992: Reappraisal of the Baltic Amber Curculionoidea described by E. Voss. - Mitteilungen aus dem Geologisch-Paläontologischen Institut der Universität Hamburg 73: 191-215.

Lawrence, J. F., Beutel, R. G., Leschen, R. A. B., Ślipiński, S. A. 2010: Chapter 2. Glossary of Morphological Terms. - Handbook of Zoology. Arthropoda: Insecta. Tb. 40: Coleoptera (Beetles). Vol. 2: Morphology and Systematics (Elateroidea, Bostrichformia, Cucujiformia partim): 9-20.

Legalov, A. A. 2012: New and little known Apioninae (Coleoptera, Brentidae) in Eocene Baltic amber. Evraziatskii entomologicheskii Zhurnal 11(3): 219 222.

Legalov, A. A. 2013: New and little known weevils (Coleoptera: Curculionoidea) from the Paleogene and Neogene. - Historical Biology 25(1): 59-80.

Legalov, A. A. 2014: New Nemonychidae, Brentidae and Curculionidae (Coleoptera: Curculionoidea) from the Turonian of Kzyl-Dzhar (Kazakhstan). - Historical Biology 26(5): 675-689.

Legalov, A. A. 2015a: First record of the weevil subfamily Nanophyinae (Coleoptera, Brentidae) from the Eocene of the Green River, United States. - Paleontological Journal 49(4): 399-401.

Legalov, A. A. 2015b: Fossil Mesozoic and Cenozoic weevils (Coleoptera, Obrienioidea, Curculionoidea). Paleontological Journal 49(13): 1442-1513.

Legalov, A. A. 2018a: A new tribe of the subfamily Cyladinae (Coleoptera, Brentidae) in the Miocene of Germany. - Paleontological Journal 52(1): 35-38.

Legalov, A. A. 2018b: Annotated key to weevils of the world. Part 1. Families Nemonychidae, Anthribidae, Belidae, Ithyceridae, Rhynchitidae, Brachyceridae and Brentidae. - Ukrainian Journal of Ecology 8(1). (In press.)

Legalov, A. A. 2018c: New weevils (Coleoptera, Curculionoidea) from Eocene of Green River. Part 1. - Paleontological Journal 52(3). (In press.)

Legalov, A. A. \& Bukejs, A. 2015: Succinapion telnovi n. gen. et n. sp. of the tribe Kalcapiini (Coleoptera: Brentidae: Apioninae) in Baltic amber. - Historical Biology 26(5): 603-607.

Lutz, H. 1990: Systematische und palökologische Untersuchungen an Insekten aus dem Mittel-Eozän der Grube Messel bei Darmstadt, Frankfurt am Main. - Courier Forschungsinstitut Senckenberg 124: 1-165.

Oberprieler, R. G. 2014a: 3.6. Brentidae Billberg, 1820. Handbook of Zoology. Arthropoda: Insecta. Tb. 40:
Coleoptera (Beetles). Vol. 3: Morphology and Systematics (Phytophaga): 363.

Oberprieler, R. G. 2014b: 3.6.1 Eurhynchinae Lacordaire, 1863, Ithycerinae Schoenherr, 1823 and Microcerinae. - Handbook of Zoology. Arthropoda: Insecta. Tb. 40: Coleoptera (Beetles). Vol. 3: Morphology and Systematics (Phytophaga): 364-383.

Poinar, G. Jr., 2009: Dominibrentus leptus, n. gen., n. sp. (Curculionoidea, Brentidae, Cyphagoginae, Dominibrentini, n. tribe), a straight-snouted weevil in Dominican amber. - Historical Biology 21(1-2): 51-55.

Poinar, G. Jr. \& Legalov, A. A. 2015: New Apioninae (Coleoptera: Brentidae) in Dominican amber. - Historical Biology 27(2): 134-157.

Ritzkowski, S. 1997: K-Ar-Altersbestimmungen der bernsteinführenden Sedimente des Samlandes (Paläogen, Bezirk Kaliningrad). - Metalla (Sonderheft) 66: 19-23.

Sadowski, E.-M., Schmidt, A. R., Kunzmann, L., Gröhn, C. \& Seyfullah, L. J. 2016: Sciadopitys cladodes from Eocene Baltic amber. - Botanical Journal of the Linnean Society 180(2): 258-268.

Scudder, S. H. 1893: Rhynchophorus Coleoptera of the United States. - Monographs of the United States Geological Survey 21: 1-206.

Théobald, N. 1937: Les insectes fossiles des terrains oligocènes de France. - Bulletin mensuel de la Société des sciences de Nancy 1: 1-473.

Tröster, G. 1993: Wasserkäfer und andere Raritäten Neue Coleoptera-Funde aus den mitteleozänen Tonsteinen der Grube Messel bei Darmstadt. — Kaupia 2: 145-154.

Voss, E. 1953: Einige Rhynchophoren der Bernsteinfauna (Col.). - Mitteilungen des geologischen Staatsinstitutes von Hamburg 22: 119-140.

Voss, E. 1972: Einige Rüsselkäfer der Tertiärzeit aus Baltischem Bernstein (Coleoptera, Curculionoidea). Steenstrupia 2: 167-181.

Wagner, H. 1924: Ein neues Apion aus dem baltischen Bernstein (Coleoptera, Curculionidae). - Deutsche Entomologische Zeitschrift: 134-136.

Wappler, T. 2003: Die Insekten aus dem Mittel-Eozän des Eckfelder Maares, Vulkaneifel. — Mainzer Naturwissenschaftliches Archiv 27: 1-234.

Wanat, M. 2001: Genera of Australo-Pacific Rhadinocybinae and Myrmacicelinae, with biogeography of the Apionidae (Coleoptera: Curculionoidea) and phylogeny of the Brentidae (s. lato). - Olsztyn, Mantis. 432 p.

Zherikhin, V. V. 1971: On weevils (Insecta, Coleoptera) from the Baltic Amber. - Modern Problems of Paleontology. Moscow: 197-209.

Zherikhin, V. V. \& Gratshev, V. G. 2004: Fossil curculionoid beetles (Coleoptera, Curculionoidea) from the Lower Cretaceous of northeastern Brazil. — Paleontological Journal 38(5): 528-537. 